\title{
PENGARUH PERSEPSI MAHASISWA TENTANG BUDAYA SEKOLAH TERHADAP MOTIVASI BELAJAR MAHASISWA DI STAB NEGERI SRIWIJAYA
}

\author{
Oleh \\ Mulyana \\ mulyanawahyu45@gmail.com
}

\begin{abstract}
This research aimed to investigate the effect of student perceptions of school culture on motivation to learn at The Sriwijaya Buddhist State College. The method used in this research is descriptive quantitative. The results showed the influence students' perceptions of school culture on motivation to learn at The Sriwijaya Buddhist State College. The results indicate where data processing $\left(F_{\text {hitung }}\right.$ variable students' perceptions of school culture $(X)$ on learning motivation variable $(Y)$ amounted to 35.482 , while the value of $F_{\text {table }}$ for $n=76$ is 6.99 . The adjusted $R^{2}$ value (adjusted $R$ Square) of 0.315 or $31.5 \%$ showed the strength of the influence of students' perceptions of school culture on motivation to learn. There are other factors that can affect motivation $68.5 \%$ were not examined in this study. From data processing obtained by simple linear regression equation: $Y=71.234+0.345 X$, which indicates that the increase in students' perceptions of school culture would contribute to student learning motivation at 0.345 .
\end{abstract}

Keywords: Preception, School Culture, Learning Motivation

\section{Pendahuluan}

Perguruan tinggi merupakan institusi pendidikan yang menyelenggarakan pendidikan tinggi dengan fungsi dan peran sangat strategis dalam mewujudkan amanat Undang-Undang Nomor 20 Tahun 2003 tentang Sistem Pendidikan Nasional, yaitu menghasilkan lulusan yang berahlak mulia, jujur, berkualitas, demokratis, dan memiliki kemampuan untuk menghadapi tantangan dan persaingan global yang tidak dapat dihindari. Untuk mewujudkan peran dan fungsi tersebut, perguruan tinggi haruslah memiliki kualitas yang dapat diandalkan. Kualitas suatu organisasi tidak datang dengan serta merta tetapi harus dibangun setahap demi setahap sehingga membentuk suatu budaya yang diyakini dapat membantu mewujudkan kemajuan di masa depan. Budaya sekolah harus berfokus pada pencapaian visi dan misi, mampu menciptakan komunikasi baik formal dan informal untuk seluruh warga sekolah, inovatif dan berani mengambil resiko dari konsekuensi budaya yang dibangun, dan memiliki strategi yang jelas dalam pencapaian tujuan sekolah. Selain itu, 1।Jurnal Vijjacariya Vol.3 Nomor 1 Tahun 2016 
budaya sekolah juga harus berfokus pada kinerja, membangun sistem evaluasi yang jelas, memiliki komitmen yang kuat, menciptakan pengambilan keputusan partisipatif, dan mampu melakukan evaluasi diri dengan objektif dalam menilai kekuatan dan kelemahan. Budaya sekolah yang berfokus pada hal-hal demikian merupakan syarat yang harus dipenuhi dalam upaya pencapaian tujuan yang sudah ditetapkan. Budaya sekolah juga berhubungan dengan bagaimana setiap warga sekolah membangun komitmen untuk mewujudkan visi, misi, dan tujuan yang telah ditetapkan dalam upaya menghasilkan output dan outcome yang berkualitas.

Sekolah Tinggi Agama Buddha (STAB) Negeri Sriwijaya sebagai salah satu perguruan tinggi yang bercirikan keagamaan Buddha turut memikul tanggung jawab untuk dapat mewujudkan fungsi dan peran dalam menghasilkan lulusan yang berakhlak mulia, jujur, berkualitas, demokratis dan memiliki kemampuan untuk menghadapi tantangan dan persaingan global. Dalam upayanya menghasilkan lulusan yang berkualitas, STAB Negeri Sriwijaya telah berupaya untuk membangun suatu budaya yang diyakini dapat membantu mewujudkan cita-cita tersebut.

STAB Negeri Sriwijaya sebagai sebuah perguruan tinggi yang mulai berdiri tahun 2002 dengan status swasta dan berubah status menjadi negeri pada tahun 2005 memiliki budaya tersendiri yang dibentuk dan dipengaruhi oleh nilai-nilai, persepsi, kebiasaan-kebiasaan, kebijakan-kebijakan akademis dan non-akademis, dan perilaku orang-orang yang berada di dalam sekolah tersebut, terutama dari para pendiri atau penggagas STAB Negeri Sriwijaya. Dalam membangun STAB Negeri Sriwijaya, para pendiri memiliki cita-cita, tujuan, dan nilai-nilai tertentu yang hendak diwijudkan. STAB Negeri Sriwijaya sebagai institusi pendidikan yang masih relatif muda dan dengan keterbatasan sumber daya manusia yang dimiliki, mengalami banyak kendala dalam menciptakan budaya sekolah yang baik.

Permasalahan-permasalahan yang muncul bersifat teknis dan non-teknis, seperti berkaitan dengan status kepemimpinan yang saat ini masih kesulitan untuk dapat memiliki ketua yang definitif dan harus mencari calon ketua dari luar lingkungan STAB Negeri Sriwijaya, hubungan yang kurang kondusif antara 
pegawai struktural dan fungsional, komitmen, dan kinerja yang belum mengarah pada pencapaian visi dan misi secara maksimal. Ketika STAB Negeri Sriwijaya telah memiliki ketua definitif tetapi berasal dari luar lingkungan STAB Negeri Sriwijaya, maka kendala yang dihadapi berikutnya adalah ketua baru harus mempelajari terlebih dahulu karakteristik budaya organisasi yang sudah ada di STAB Negeri Sriwijaya sehingga membutuhkan waktu untuk menyesuaikannya. Bagaimanapun, sosok pimpinan sangat dibutuhkan seluruh warga kampus. Budaya organisasi serta kinerja dosen dan pegawai sangat dipengaruhi oleh faktor pimpinan.

Beberapa contoh di atas menunjukkan bahwa budaya organisasi di STAB Negeri Sriwijaya belum menunjukkan ke arah pencapaian tujuan institusi. Permasalahan yang muncul memberikan pengaruh yang tidak baik pada kinerja pegawai, baik struktural maupun fungsional. Selain itu, permasalahanpermasalahan tersebut juga berpengaruh pada tingkat kepercayaan mahasiswa terhadap kredibilitas institusi. Pendapat mahasiswa yang menganggap bahwa kuliah di STAB Negeri Sriwijaya adalah mudah, pasti lulus, dan kebijakan yang diambil mudah berubah, menunjukkan bahwa budaya sekolah yang dibangun belum tertata dengan rapi. Pandangan-pandangan miring mengenai institusi haruslah disikapi dengan bijak. Tanggapan positif dapat dilakukan dengan refleksi kembali terhadap budaya yang sudah berlaku di STAB Negeri Sriwijaya dan dilanjutkan dengan melakukan pembenahan sehingga tercipta budaya sekolah yang benar-benar berorientasi pada tercapainya tujuan.

Budaya sekolah memiliki pengaruh yang signifikan terhadap motivasi dan kinerja seluruh warga sekolah, termasuk motivasi belajar dan berprestasi mahasiswa. Motivasi belajar merupakan salah satu faktor yang dapat menentukan keberhasilan akademik dan non-akademik mahasiswa. Adanya motivasi dapat diamati melalui semangat dan kegigihan mahasiswa dalam belajar. Pengamatan sementara menunjukkan fakta bahwa motivasi belajar mahasiswa relatif rendah, yang ditunjukkan dengan masih ada beberapa mahasiswa belum membayar uang semesteran meskipun jadwal perkuliahan 
sudah dimulai beberapa pertemuan. Selain itu, masih ada beberapa mahasiswa yang lebih mementingkan bekerja daripada mengikuti perkuliahan. Hasil wawancara dengan beberapa mahasiswa juga menunjukkan bahwa motivasi belajarnya masih kurang. Masih ada mahasiswa yang hanya belajar ketika akan menghadapi ujian semester, kuis, tugas, maupun ketika mendapatkan tugas dari dosen. Mahasiswa lebih memilih bermain game online, mengakses facebook, dan lainnya yang tidak berhubungan dengan usaha pencapaian prestasi akademik.

Penelitian ini bertujuan untuk mengetahui pengaruh presepsi mahasiswa tentang budaya sekolah terhadap motivasi belajar mahasiswa di STAB Negeri Sriwijaya. Beberapa manfaat yang dapat diperoleh dari penelitian ini, yaitu: (1) teori tentang kajian budaya sekolah di lingkungan Sekolah Tinggi Keagamaan Buddha; (2) terhadap kebijakan pengembangan konsep budaya sekolah di STAB Negeri Sriwjaya; dan (3) mendorong peneliti lain melakukan penelitian lebih mendalam mengenai permasalahan budaya sekolah di lingkungan perguruan tinggi keagamaan Buddha di Indonesia.

\section{Kajian Pustaka}

Istilah persepsi berasal dari bahasa Latin "perception", yang berarti menerima atau mengambil (Desmita, 2010: 117). Kreitner dan Kinicki (2010) dalam Wibowo (2013: 59) mendefinisikan persepsi sebagai proses kognitif yang memungkinkan manusia menginterpretasikan dan memahami lingkungan di sekitarnya. Persepsi dimaknai sebagai aktivitas mental dalam usaha memaknai dan memahami sesuatu. Hal senada juga dinyatakan oleh Rakhmat (2012: 51) yang mengartikan persepsi sebagai pengalaman tentang objek, peristiwa, atau hubungan-hubungan yang diperoleh dengan menyimpulkan informasi dan menafsirkan pesan. Dalam presepsi terjadi proses menghubungkan pengetahuan yang sudah dimiliki dengan stimulus baru yang diterima individu. Kemampuan untuk membeda-bedakan, mengelompokkan, memfokuskan dan sebagainya, yang selanjutnya diinterpretasikan disebut persepsi (Sarwono, 2012: 86). Leavitt (1978) dalam Sobur (2011: 445) mengartikan persepsi dalam makna sempit sebagai pengelihatan, bagaimana cara seseorang melihat sesuatu; sedangkan 
dalam makna luas sebagai pandangan atau pengertian, yaitu bagaimana seseorang memandang atau mengartikan sesuatu. Robbins (2001: 88) mendefinisikan persepsi sebagai suatu proses dengan mana individu-individu mengorganisasikan dan menafsirkan kesan indera untuk memberikan makna pada lingkungan. Pareek (1996) dalam Sobur (2011: 446) mendefinisikan persepsi sebagai proses menerima, menyeleksi, mengorganisasikan, mengartikan, menguji, dan memberikan reaksi kepada rangsangan panca indera atau data. Tampubolon (2012:65) mengartikan persepsi sebagai gambaran seseorang tentang suatu objek yang menjadi fokus permasalahan yang sedang dihadapi. Meskipun demikian, persepsi sebagai aktifitas kognitif tidak berdiri sendiri tetapi melibatkan proses kognitif lain.

Robins dan Timothy Judge (2011) dalam Wibowo (2013: 60-61) mengemukakan tiga faktor yang mempengaruhi persepsi seseorang, yaitu: (1) orang yang memberikan persepsi (perceiver); (2) orang atau objek yang menjadi sasaran persepsi (target); dan (3) keadaan saat persepsi dilakukan (situasi). Ada beberapa hal yang menentukan kualitas dari persepsi yang bersumber dari orang yang melakukan persepsi, yang meliputi: sikap (attitudes) individu terhadap , motif (motives), minat atau kepentingan (interset), pengalaman (experience), dan harapan (expectations). Berkaitan dengan orang atau objek yang menjadi sasaran persepsi (target), mencakup: sesuatu yang baru (novelty), gerakan (motion), suara (sounds), besaran atau ukuran (size), latar belakang (background), kedekatan (proximity), dan kesamaan (similarity). Berkenaan dengan keadaan saat persepsi dilakukan (situasi), yang mencakup: waktu (time), pengaturan kerja (work setting), dan pengaturan sosial (social setting).

Sekolah sebagai suatu organisasi memiliki nilai-nilai dan cita-cita yang diyakini dapat diwujudkan di masa depan. Budaya sekolah merupkan penjabaran dari nilai-nilai yang diterapkan, norma yang ada dan berlaku, serta harapan dan kebiasaan yang menggambarkan interaksi timbal balik antara satu anggota dengan lainnya di sekolah (Hidayat dan Asroi, 2013: 151). Hasil penelitian yang dilakukan oleh Macneil, dkk. (2009: 77) menunjukkan bahwa 
strong school culture have better motivated teachers. Highly motivated teachers have greater success in terms of student performance and student outcomes. Hasil penelitian tersebut menunjukkan budaya sekolah yang kuat akan berdampak positif pada tingginya motivasi guru, yang akhirnya akan memberikan pengaruh positif pada tingginya penampilan dan keluaran siswa. Budaya merupakan sesuatu yang unik, artinya setiap sekolah memiliki ciri khas masing-masing berkaitan dengan budaya yang berlaku dan diyakini oleh masing-masing anggota sekolah.

Stolp dan Smith (1995: 13) define school culture as historically transmitted patterns of meaning that include the norms, values, beliefs, traditions, and myths understood, maybe in varying degrees, by members of the school community. Maslowski (2001: 9-10) defines school culture as the basic assumptions, norms and values, and cultural artifacts that are shared by school members, which influence their functioning at school. Fullan (2007) dalam Waldron dan McLeskey (2010: 59) mendefinisikan budaya sekolah sebagai the guiding beliefs and expectations evident in the way a school operates. A school's culture is immedietly evident when one sets foot on campus, that show in hallway decorations, the way students interect with others on campus and attitudes about the :coolness" of academic success (Corwin dan Tierney, 2007: 1). Dari beberapa pengertian budaya sekolah, dapat disimpulkan bahwa budaya sekolah adalah penjabaran dari nilai-nilai yang diterapkan, norma yang ada dan berlaku, serta harapan dan kebiasaan yang menggambarkan interaksi timbal balik antara satu anggota dengan lainnya di sekolah dapam upaya pencapaian tujuan atau cita-cita sekolah yang diharapkan di masa depan.

McClafferty dan McDonough dalam (Corwin dan Tierney, 2007: 3-6) mengemukakan lima aspek dalam membangun budaya dan akses kampus, yaitu: (1) academic momentum; (2) an understanding of how college plans develop; (3) a clear mission statement; (4) comprehensive college services; and (5) coordinated and systemic college support. Deal dan Kennedy (1984) dalam Lunenburg (2011: 4-6) mengidentifikasi empat dimensi dari budaya organisasi, yaitu: values, heroes, rites and rituals, dan communication network, dimana keempatnya memainkan peran penting dalam menciptakan budaya organisasi. Nilai (values) merupakan kriteria umum, standar, atau prinsip-prinsip yang mengarahkan perilaku dari setiap anggota organisasi. Pemimpin (heroes) dengan visi yang jelas akan membawa 
kemajuan organisasi. Nilai-nilai budaya organisasi tersebut dapat pula diterapkan pada institusi pendidikan.

Motivasi belajar merupakan salah satu faktor penting dalam menentukan keberhasilan siswa dalam belajar. Student motivation is used to explain the degree to which students invest attention and effort in various pursuits, which may or may not be the ones desired by their teachers (Brophy, 2004:4). Tingkat motivasi siswa dapat ditandai melalui seberapa besar siswa menginvestasikan perhatian dan usahanya dalam berbagai kegiatan. Dengan demikian, motivasi belajar merupakan sesuatu hal yang membuat siswa ingin melakukan hal yang ingin dicapai, sesuatu yang membuat tetap ingin melakukannya, dan membantu dalam menyelesaikan tugas-tugas akademiknya. Motivasi belajar adalah dorongan internal dan eksternal pada siswa yang sedang belajar untuk mengadakan perubahan tingkah laku pada umumnya dengan beberapa indikator atau unsur yang mendukung (Uno, 2008: 72). Motivasi belajar dapat berasal dari dalam diri maupun dari luar diri siswa, bergantung dari karakteristik dan keperibadiannya.

Siswa yang memiliki motivasi belajar adalah individu yang memiliki tujuan yang diharapkan dalam belajar, selain itu adanya sikap ulet, gigih, tidak putus asa dalam menyelesaikan tugas dan memcahkan masalah. Dengan mengetahui prinsip $5 \mathrm{~W}+1 \mathrm{H}$, seorang mahasiswa dapat mengetahui seberapa besar motivasi belajarnya di perguruan tinggi (Sudarman, 2004: 88). Prinsip $5 \mathrm{~W}+1 \mathrm{H}$ yang dimaksud adalah: (1) what: apa yang dipelajari (materi atau objek); (2) why: mengapa dipelajari? (3) when: kapan harus mempelajari; (4) who: siapa yang dipelajari (pemikiran atau teori dari para pakar atau ilmuwan); (5) where; di mana dipelajari (di kelas, laboratorium, di rumah, di perpustakaan); dan (6) how: bagaimana mempelajarinya. Dari beberapa pengertian motivasi belajar di atas, dapat disimpulkan bahwa motivasi belajar adalah dorongan mental yang menggerakkan dan mengarahkan perilaku siswa untuk belajar, dimana kebutuhan, dorongan, dan tujuan merupakan komponen utama yang menyebabkan seorang siswa belajar. 
Saefullah (2012: 292) mengemukakan enam faktor yang memengaruhi motivasi belajar siswa, yaitu: (1) cita-cita atau aspirasi yang menjadi target untuk dicapai; (2) kemampuan belajar, yang merupakan taraf perkembangan berfikir siswa; (3) kondisi siswa, yang dapat berupa kondisi fisik dan psikologis; (4) kondisi lingkungan, berupa keluarga, sekolah, dan masyarakat; (5) unsur-unsur dinamis dalam belajar yang keberadaannya tidak stabil, seperti kadang-kadang kuat, lemah, atau hilang sama sekali; dan (6) upaya guru membelajarkan siswa, yang merupakan upaya-upaya yang dilakukan guru untuk memotivasi siswa. Reid (2009: 19-24) mengemukakan beberapa faktor yang dapat menimbulkan motivasi belajar, antara lain: (1) motivasi karena tugas; (2) motivasi karena penghargaan; (3) motivasi social (karena pengaruh kelompok teman sebaya); (4) motivasi karena umpan balik; (5) motivasi karena pencapaian prestasi; (6) lingkungan yang memotivasi; dan (7) sekolah yang memberi motivasi.

Woolfolk (2009: 227) mengemukakan enam faktor yang dapat membangkitkan motivasi untuk belajar jika dimunculkan secara bersama-sama, yaitu: (1) sumber motivasi berasal dari dalam (motivasi intrinsik) yang merupakan faktor-faktor personal, seperti kebutuhan, interes/minat, rasa ingin tahu, dan kegembiraan; (2) tipe tujuan yang ditetapkan dapat memenuhi kepuasan pribadi jika memenuhi tantangan dan mengalami peningkatan, yang dapat dinyatakan dalam keenderungan untuk memilih tujuan dengan tingkat kesulitan sedang dan menantang; (3) tipe keterlibatan (task-involved) yang peduli pada penguasaan tugas; (4) motivasi untuk berprestasi (mastery orientation); (5) kemungkinan atribusi, dimana kesuksesan dan kegagalan diatribusikan pada usaha dan kemampuan yang dapat dikontrol; dan (6) keyakinan tentang kemampuan, dimana keyakinan tentang kemampuan dapat ditingkatkan melalui kerja keras dan pengetahuan serta keterampilan tambahan.

Rusman (2014: 439) mengemukakan bahwa peserta didik akan termotivasi dalam belajar jika: (1) dirinya yakin bahwa apa yang dipelajari bermanfaat bagi dirinya; (2) dirinya yakin akan mampu memahami/menguasai pelajaran tersebut; dan (3) iklim/situasi belajar yang menyenangkan bagi dirinya. Artinya, peserta didik akan termotivasi untuk belajar jika materi pelajaran bermanfaat dan mengetauhu bahwa mampu mencapainya. Guru harus 
memberikan penjelasan berkaitan dengan manfaat mempelajari suatu materi pelajaran dan dengan usaha yang cukup maka setiap siswa dapat menguasainya. Dorongan semangat dari guru merupakan motivasi bagi siswa dalam meningkatkan keyakinan untuk dapat menguasai suatu materi peajaran. Selain itu, suasana kelas yang kondusif merupakan syarat penting dalam menciptakan motivasi belajar peserta didik. Untuk menciptakan suasana yang kondusif, maka guru harus dapat mengelola kelas dengan baik.

Sardiman (2006: 83) mengemukakan 9 ciri yang menunjukkan seseorang memiliki motivasi, yaitu: (1) tekun menghadapi tugas (dapat bekerja terus menerus dalam waktu yang lama, tidak pernah berhenti sebelum selesai); (2) ulet menghadapi kesulitan (tidak lekas putus asa); (3) menunjukkan minat terhadap bermacam-macam masalah (minat untuk sukses); (4) mempunyai orientasi ke masa depan; (5) lebih senang bekerja mandiri; (6) cepat bosan pada tugas-tugas yang rutin (hal-hal yang bersifat mekanis, berulang-ulang, sehingga kurang kreatif); (7) dapat mempertahankan pendapatnya (kalau sudah yakin akan sesuatu); (8) tidak mudah melepaskan hal yang sudah diyakini; dan (9) senang mencari dan memecahkan masalah soal-soal. Sedangkan Paryati Sudarman (2004: 83) menjelaskan bahwa mahasiswa yang memiliki motivasi kuat akan memiliki sikap, seperti: (1) selalu memelihara kesungguhan, ketekunan dan semangat dalam belajar; (2) pantang menyerah; (3) kuat terhadap berbagai godaan, baik yang datang dari dalam maupun dari luar; (4) pandai bergaul dan tetap menjaga hubungan baik dengan sesama; dan (5) menjalankan perintah agama serta meninggalkan hal-hal yang dilarang.

\section{Metode Penelitian}

Penelitian ini menggunakan metode penelitian deskriptif kuantitatif. Basuki (2006: 110) mengemukakan bahwa penelitian deskriptif dapat dilakukan secara kuantitatif agar dapat dilakukan analisis statistik. Metode penelitian survey adalah metode penelitian kuantitatif yang digunakan untuk mendapatkan data yang terjadi pada masa lampau atau saat ini, tentang keyakinan, pendapat, 
karakteristik, perilaku, hubungan variabel dan untuk menguji beberapa hipotesis tentang variabel sosiologis dan psikologis dari sampel yang diambil dari populasi tertentu (Sugiyono, 2013: 24).

Populasi adalah wilayah generalisasi yang terdiri atas: obyek atau subyek yang mempunyai kualitas dan karakteristik tertentu yang ditetapkan oleh peneliti untuk dipelajari dan kemudian ditarik kesimpulannya (Sugiyono, 2013: 80). Populasi dalam penelitian ini adalah mahasiswa STAB Negeri Sriwijaya, Jurusan Dharmacarya dan Dharmaduta semester 3, 5, dan 7, sebanyak 92 mahasiswa. Dengan menggunakan rumus Slovin, untuk kelonggaran ketidaktelitian 5\% atau 0,05 diperoleh 75 sampel, yang merupakan jumlah minimal sampel yang harus digunakan. Dalam penelitian ini digunakan sampel sebanyak 76 mahasiswa.

Metode pengumpulan data merupakan bagian integral dari desain penelitian (Sekaran, 2006: 65), sehingga harus dipersiapkan instrumen yang tepat. Instrumen pengumpulan data yang digunakan dalam penelitian ini adalah dengan angket atau kuesioner, yaitu persepsi mahasiswa tentang budaya sekolah dan motivasi belajar.

Sebelum instrumen digunakan untuk mengambil data, instrumen diuji validitas dan reliabilitas. Uji validitas instrumen yang digunakan dalam penelitian ini adalah uji validitas korelasi product moment dengan bantuan program SPSS versi 17 for Windows. Dasar pengambilan keputusan dalam uji validitas adalah sebagai berikut: (1) apabila nilai $r_{\text {hitung }}>r_{\text {tabel, maka butir }}$ instrumen dinyatakan valid; dan (2) apabila nilai $\mathrm{r}_{\text {hitung }}<\mathrm{r}_{\text {tabel }}$, maka butir instrumen dinyatakan tidak valid. Untuk menentukan validitas butir instrumen digunakan harga kritis pada tabel product moment untuk N-2 diperoleh $\mathrm{r}_{\text {tabel }}$ sebesar 0.223. Dari hasil uji validitas instrumen persepsi mahasiswa terhadap budaya sekolah diperoleh keterangan bahwa dari 52 butir instrument terdapat $3,85 \%$ atau 2 item yang tidak valid, yaitu no. 2, 41. Sedangkan pada uji validitas instrumen motivasi belajar diperoleh keterangan bahwa dari 40 butir instrument terdapat 15,0\% atau 6 butir instrumen yang tidak valid, yaitu no. 8, 11, 21, 25, 28, dan 30. 
Uji reliabilitas dalam penelitian ini menggunakan rumus Alpha dengan menggunakan bantuan program SPSS versi 17. Batas penentuan reliabilitas menggunakan acuan dari Aiken (1995) dalam Purwanto (2007: 185) yang memberikan batas minimal koefisien reliabilitasnya paling tidak 0,85. Hasil uji reliabilitas instrumen untuk persepsi mahasiswa tentang budaya sekolah diperoleh koefisien Alpha Cronbach sebesar $0.951>$ dari 0,85, sehingga disimpulkan bahwa hasil uji instrument budaya sekolah adalah reliabel. Hasil uji reiabilitas instrumen untuk motivasi belajar diperoleh koefisien Alpha Cronbach sebesar $0,898>$ dari 0,85 , sehingga disimpulkan bahwa instrumen motivasi belajar adalah reliabel.

\section{Hasil dan pembahasan}

\section{Deskripsi Data}

Deskripsi data yang disajikan merupakan gambaran secara umum mengenai penyebaran data yang diperoleh dari hasil penyebaran kuesioner kepada 76 mahasiswa STAB Sriwijaya. Data yang disajikan merupakan hasil pengolahan dengan menggunakan formula statistik deskriptif bantuan program SPSS versi 17. Statistik deskriptif yang disajikan, antara lain: skor maksimum (maksimum score), skor minimum (minimum score), rentang (range), pemusatan data (mean), dan simpangan baku (standard deviation).

Data persepsi mahasiswa tentang budaya sekolah diperoleh dari hasil penyebaran kuesioner adalah sebagai berikut: Skor Maksimum: 228,00; Skor Minimum: 121,00; Rentang: 112,00; Rerata: 185,2105; dan Simpangan Baku: 21,60143. Dari data tersebut dapat ditentukan tingkat persepsi mahasiswa tentang budaya sekolah dalam 3 kategoriseperti yang ditunjukkan pada tabel 1.1.

Tabel 1.1 Kriteria Pengelompokan Persepsi Mahasiswa tentang Budaya Sekolah

\begin{tabular}{|l|l|l|}
\hline \multicolumn{1}{|c|}{ Kriteria Pengelompokan } & \multicolumn{1}{c|}{ Hasil Hitung } & \multicolumn{1}{c|}{ Kriteria } \\
\hline Skor total $\geq$ Mean + SD & Skor total $\geq 207$ & Tinggi \\
\hline Mean - SD $\leq$ skor total $<$ Mean + SD & $164 \leq$ skor total $<207$ & Sedang \\
\hline Skor total $<$ Mean - SD & Skor total $<164$ & Rendah \\
\hline
\end{tabular}


Dari hasil perhitungan diperoleh tingkat persepsi mahasiswa terhadap budaya sekolah adalah sebagai berikut: jumlah mahasiswa yang memiliki persepsi tinggi sebanyak 18 orang atau $23,7 \%$; jumlah mahasiswa yang memiliki persepsi sedang sebanyak 49 orang atau $64,5 \%$; dan jumlah yang mahasiswa yang memiliki perspsi rendah sebanyak 9 orang atau 11,8\%.

Data motivasi belajar yang diperoleh dari hasil penyebaran adalah sebagai berikut: Skor Maximum: 161,00; Skor Minimum: 91.00; Rentang: 70,00: Rerata; 137,5526; dan Simpangan Baku: 13,37898. Dari data tersebut dapat ditentukan tingkat motivasi belajar dalam 3 kategori, seperti yang ditunjukkan pada tabel berikut:

Tabel 1.2 Kriteria Pengelompokan Motivasi Belajar

\begin{tabular}{|l|l|l|}
\hline \multicolumn{1}{|c|}{ Kriteria Pengelompokan } & \multicolumn{1}{c|}{ Hasil Hitung } & \multicolumn{1}{c|}{ Kriteria } \\
\hline Skor total $\geq$ Mean + SD & Skor total $\geq 151$ & Tinggi \\
\hline Mean - SD $\leq$ skor total $<$ Mean + SD & $124 \leq$ skor total $<151$ & Sedang \\
\hline Skor total $<$ Mean - SD & Skor total $<124$ & rendah \\
\hline
\end{tabular}

Dari hasil perhitungan diperoleh keterangan bahwa kategori tingkat motivasi belajar adalah sebagai berikut: jumlah mahasiswa yang memiliki persepsi tinggi sebanyak 12 orang atau 15,8\%; jumlah mahasiswa yang memiliki persepsi sedang sebanyak 49 orang atau 71,1\%; dan jumlah yang mahasiswa yang memiliki perspsi rendah sebanyak 10 orang atau 13,1 \%.

\section{Uji Prasyarat}

Dalam penelitian ini, uji prasyarat yang digunakan adalah uji normalitas dan uji linearitas. Uji normalitas yang dilakukan dalam penelitian ini menggunakan Kolmogorov-Smirnov Tes tipe Undstandardized Residual dengan bantuan program SPSS 17, dimana hasil yang diperoleh disajikan dalam tabel berikut.

Tabel 1.3 Uji Normalitas Data

\begin{tabular}{|c|c|c|c|}
\hline & $\begin{array}{c}\text { Kolomogorov- } \\
\text { Smirnov }\end{array}$ & Signifikansi & Keterangan \\
\hline $\begin{array}{c}\text { Unstandardized } \\
\text { Residual }\end{array}$ & 0,549 & 0,924 & Normal \\
\hline
\end{tabular}


Data dinyatakan berdistribusi normal jika nilai signifikansinya lebih besar dari 0,05. Dari hasil uji normalitas diperoleh nilai signifikansi sebesar 0,924. Dengan demikian, data yang digunakan dalam penelitian adalah berdistribusi normal (nilai sig. lebih besar dari 0,05).

Uji linearitas digunakan untuk menguji apakah persepsi mahasiswa tentang budaya sekolah (variable $\mathrm{X}$ ) dan motivasi belajar (vaiabel Y) bersifat linier. Kriteria penerimaan hubungan antara variabel $X$ dan variabel $Y$ jika nilai signifikansi kurang dari 0,05. Uji linearitas yang dilakukan dengan menggunakan bantuan program SPSS 17, diperoleh hasil yang disajikan dalam tabel berikut.

Tabel 1.4 Hasil Uji Linieritas

\begin{tabular}{|c|c|c|c|c|}
\hline \multicolumn{2}{|c|}{ Linieritas } & F & Signifikansi & Keterangan \\
\hline $\begin{array}{c}\text { Variabel } \\
\text { Bebas }\end{array}$ & $\begin{array}{c}\text { Variabel } \\
\text { Terikat }\end{array}$ & 56,984 & 0,00 & Linier \\
\hline
\end{tabular}

Dari tabel di atas, diperoleh nilai signifikansi dari linieritas sebesar 0,00. Dengan demikian, hubungan yang terjadi antara variabel persepsi mahasiswa tentang budaya sekolah sebagai variabel bebas $(X)$ dan motivasi belajar sebagai variabel terikat $(\mathrm{Y})$ bersifat linier karena nilai siknifikansinya 0,00 (kurang dari $0,05)$.

\section{Hasil Pengujian Hipotesis}

Pengujian hipotesis dalam penelitian ini menggunakan analisis regresi linier sederhana karena hanya melibatkan dua variabel, yaitu persepsi mahasiswa tentang budaya sekolah dan motivasi belajar. Pengujian hipotesis dilakukan dengan bantuan program SPSS versi 17. Tabel 1.5 menunjukkan hasil uji kekuatan hubungan antara persepsi mahasiswa tentang budaya sekolah dan motivasi belajar. Berdasarkan tabel tersebut, maka dapat ditarik kesimpulan bahwa terdapat adanya hubungan antara persepsi mahasiswa tentang budaya sekolah dan motivasi belajar yang ditunjukkan oleh nilai $\mathrm{R}$ sebesar 0,569, yang menunjukkan bahwa 56,9\% presepsi mahasiswa tentang budaya sekolah berhubungan dengan motivasi belajar Menurut kategori yang disusun oleh 13|Jurnal Vijjacariya Vol.3 Nomor 1 Tahun 2016 
Robert Koenker(1961) dalam Morissan (2014:379-378), maka tingkat korelasi antara persepsi mahasiswa tentang budaya sekolah terhadap motivasi belajar dalam kategori cukup/sedang, yaitu nilai R berada pada kisaran 0,40 - 0.59.

Tabel 1.5 Koefisien Korelasi

\begin{tabular}{|c|c|c|}
\hline $\mathrm{R}$ & $\mathrm{R}^{2}$ & $\mathrm{R}^{2}$ yang Disesuaikan \\
\hline 0,569 & 0,324 & 0,315 \\
\hline
\end{tabular}

Untuk menentukan apakah pengaruh dari variabel bebas signifikan atau tidak terhadap variabel terikat digunakan uji F dan nilai signifikansinya. Dasar pertimbangan untuk memutuskan apakah pengaruh variabel bebas signifikan terhadap variabel terikat adalah: Jika $F_{\text {hitung }}>F_{\text {tabel }}$ dan nilai signifikansi kurang dari 0,05, maka pengaruhnya adalah signifikan. Jika $F_{\text {hitung }}<\mathrm{F}_{\text {tabel }}$ dan nilai signifikansi lebih besar dari 0,05, maka pengaruhnya tidak siknifikan atau tidak ada pengaruh. Untuk $\mathrm{N}-2$ diperoleh $\mathrm{F}_{\text {tabel }}$ sebesar 6,99.

Tabel 1.6 Hasil Uji F

\begin{tabular}{|l|r|r|r|c|c|}
\hline \multicolumn{1}{|c|}{ Model } & \multicolumn{1}{c|}{$\begin{array}{c}\text { Jumlah } \\
\text { Kuadrat }\end{array}$} & \multicolumn{1}{c|}{ Dk } & $\begin{array}{c}\text { Rerata Jumlah } \\
\text { Kuadrat }\end{array}$ & F & Signifikansi \\
\hline Regresi & 4350.877 & 1 & 4350.877 & 35.482 & 0,000 \\
Residu & 9073.913 & 74 & 122.620 & & \\
Total & 13424.789 & 75 & & & \\
\hline
\end{tabular}

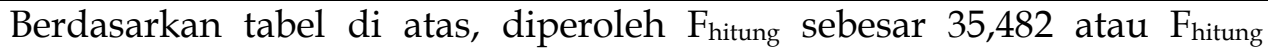
$(35,482)>F_{\text {tabel }}(6,99)$ dan nilai signifikansinya 0,00. Karena $F_{\text {hitung }}(35,482)>F_{\text {tabel }}$ $(35$,$) dan nilai signifikansinya 0,00 (lebih kecil dari 0,05), maka dapat$ disimpulkan bahwa persepsi mahasiwa tentang budaya sekolah berpengaruh secara signifikan terhadap motivasi belajar. Dengan demikian, hipotesis adanya pengaruh persepsi mahasiswa tentang budaya terhadaap motivasi belajar di STAB Sriwijaya diterima. Sedangkan untuk mengetahui seberapa besar pengaruh persepsi mahasiswa tentang budaya sekolah terhadap motivasi belajar, dapat dilihat dari nilai $\mathrm{R}^{2}$ yang telah disesuaikan (Adjusted $R$ Squqre), yaitu sebesar 0,315 atau $31,5 \%$. Artinya masih ada factor lain yang berpengaruh terhadap motivasi belajar sebesar $68,5 \%$. 
Tabel 1.7 Koefisien Regresi Linier Sederhana

\begin{tabular}{|c|c|c|c|}
\hline Model & $\begin{array}{l}\text { Unstandardized Coefficients } \\
\text { B }\end{array}$ & $\mathrm{t}$ & Signifikansi \\
\hline Konstanta & 71,324 & 6,374 & 0,000 \\
\hline BudayaSekolah & 0,349 & 5,957 & 0,000 \\
\hline
\end{tabular}

Dari tabel koefisien regresi linier sederhana di atas diperoleh persamaan regresi linier: $\mathrm{Y}=71,324+0,345 \mathrm{X}$.

\section{Pembahasan}

Dari deskripsi data diperoleh keterangan bahwa rata-rata persepsi mahasiswa tentang budaya sekolah di STAB Sriwijaya berada pada tingkat sedang, yang ditunjukkan dengan nilai rata-rata (mean) skor total sebesar 185,21. Dari pengelompokan tingkat persepsi mahasiswa tentang budaya sekolah diperoleh sebanyak 49 mahasiswa atau 64,5\% dari total sampel penelitian. Mahasiswa yang memiliki tingkat persepsi tentang budaya sekolahdalam kategori tinggi sebanyak 18 orang atau $23,7 \%$ dari total sampel penelitian. Sedangkan mahasiswa yang memiliki persepsi dalam kategori rendah hanya 9 orang atau 11,8\%. Dari hasil tersebut, diperoleh kesimpulan bahwa tara-rata mahasiswa STAB Sriwijaya memiliki persepsi tentang budaya sekolah dalam kategori sedang.

Dari deskripsi data diperoleh keterangan bahwa rata-rata motivasi belajar mahasiswa di STAB Sriwijaya berada pada tingkat sedang, yang ditunjukkan dengan nilai rata-rata (mean) skor total sebesar 137,55. Dari pengelompokan tingkat motivasi belajar diperoleh sebanyak 49 mahasiswa atau 71,1\% dari total sampel penelitian. Mahasiswa yang memiliki tingkat motivasi belajar tinggi sebanyak 12 orang atau $15,8 \%$ dari total sampel penelitian. Sedangkan mahasiswa yang memiliki motivasi belajar dengan kategori rendah hanya 10 orang atau $13,1 \%$. Dari hasil tersebut, diperoleh kesimpulan bahwa rara-rata mahasiswa STAB Sriwijaya memiliki motivasi belajar dalam kategori sedang.

Hasil pengujian hipotesis dengan menggunakan regresi linier sederhana memberikan gambaran bahwa terdapat korelasi antara persepsi mahasiswa 15|Jurna 1 Vijjacariya Vol.3 Nomor 1 Tahun 2016 
tentang budaya sekolah dan motivasi belajar. Dari nilai $\mathrm{R}$ yang diperoleh dari perhitungan sebesar 0,569 dapat disimpulkan bahwa 56,9\% persepsi mahasiswa tentang budaya sekolah berkorelasi dengan motivasi belajar. Artinya, masih ada $43,1 \%$ fator lain yang berhubungan dengan motivasi belajar.Berdasarkan kriteria yang disusun oleh Robert Koenker, maka tingkat hubungan antara persepsi mahasiswa tentang budaya sekolah dan motivasi belajar di STAB Sriwijaya berada pada tingkat sedang, yaitu berada pada kisaran 0,40 sampai dengan 0,59 .

Dari hasil uji F untuk menentukan apakah persepsi mahasiswa tentang budaya sekolah berpengaruh secara signifkan terhadap motivasi belajar diperoleh $F_{\text {hitung }}$ sebesar 35,482 . Karena $F_{\text {hitung }}(35,482)$ besar dari $F_{\text {tabel }}(6,99)$ dan nilai signifikansinya lebih kecil dari 0,05 (nilai signifikansi 0,00), maka dapat disimpulkan bahwa terdapat persepsi mahasiswa tentang budaya sekolah berpengaruh secara signifikan terhadap motivasi belajar. Dengan demikian, hipotesis yang menyatakan adanya pengaruh persepsi mahasiswa tentang budaya sekolahterhadap motivasi belajar di Sekolah Tinggi Agama Buddha Sriwijaya diterima. Budaya yang ada di STAB Sriwijaya mempengaruhi motivasi belajar mahasiswa.

Besarnya pengaruh persepsi mahasiswa tentang budaya sekolah terhadap motivasi belajar dapat dilihat dari nilai koefisien $\mathrm{R}^{2}$ yang telah disesuaikan (Ajusted R Square), yaitu sebesar 0,315 atau 31,5\%. Dari keterangan tersebut, dapat ditarik kesimpulan bahwa persepsi mahasiswa tentang budaya sekolah memberikan pengaruh terhadap motivasi belajar di STAB Sriwijaya sebesar 0,315 atau $31,5 \%$. Berarti masih ada faktor lain selain budaya sekolah yang berpengaruh terhadap motivasi beljar siswa, yaitu sebesar 0,685 atau 68,5\%.

Untuk meningkatkan motivasi belajar mahasiswa, maka dibutuhkan adanya penguatan budaya budaya sekolah yang kondusif dalam upaya pencapaian tujuan institusi. Selain itu, upaya meningkatkan motivasi, terutama motivasi intrinsik mahasiswa perlu dilakukan. Budaya sekolah merupakan faktor eksternal bagi mahasiswa. Jika faktor tersebut mampu memotivasi mahasiswa untuk belajar, maka motivasi yang muncul pada mahasiswa adalah motivasi ekstrinsik. Biasanya motivasi yang bersumber dari mitivasi ekstrinsik 16|Jurna 1 Vijjacariya Vo1.3 Nomor 1 Tahun 2016 
mudah hilang atau berkurang apabila faktor-faktor penyebabnya hilang atau berubah. Jika mahasiswa memiliki motivasi intrinsik untuk belajar, maka tidak akan terpengaruh oleh ada atau tidaknya faktor-faktor eksternal tersebut

Dari koefisien regresi linier sederhana dapat di bentuk persamaan matematis: $Y=71,324+0,345$ X. Dari persamaan tersebut, konstanta (a) bernilai besar. Artinya tanpa adanya pengaruh persepsi mengenai budaya sekolah, bahasiswa sudah memiliki motivasi belajar. diketahui koefisien regresi (b) sebesar 0,345 dan bernilai positif. Artinya, kenaikan pesepsi mahasiswa tentang budaya sekolah akan memberikan kenaikan pada motivasi belajar mahasiswa sebesar 0,345. Sedangkan penurunan nilai presepsi mahasiswa juga akan menurunkan nilai motivasi belajar. Meskipun demikian, pengaruh dari budaya sekolah memberikan kontribusi yang signifikan terhadap motivasi belajar.

\section{Penutup}

Berdasarkan hasil penelitian dan pembahasan, diperoleh kesimpulan bahwa terdapat pengaruh persepsi mahasiswa tentang budaya sekolah terhadap motivasi belajar di STAB Sriwijaya sebesar 0,315 atau 31,5\%. Persamaan regresi liner sederhana yang dihasilkan adalah: $\mathrm{Y}=71,234+0,345 \mathrm{X}$.

Dari kesimpulan yang diperoleh, dapat disampaikan beberapa saran, antara lain: (1) Budaya sekolah di STAB Sriwijaya perlu ditingkatkan kualitasnya sehingga dapat meningkatkan motivasi belajar yang akhirnya akan berkontribusi terhadap prestasi belajar mahasiswa; (2) Perlu upaya untuk meningkatkan motivasi intrinsik mahasiswa, sehingga keberadaan faktor eksternal tidak banyak berpengaruh pada motivasi belajar mahasiswa; dan (3) Perlu diadakan penelitiann lanjutan untuk mengetahui faktor lain yang mempengaruhi motivasi belajar mahasiswa sehingga prestasi mahasiswa dapat ditingkatkan.

\section{Daftar Pustaka}

Basuki, Sulistyo. 2006. Metode Penelitian. Jakarta: Wedatama Widya Sastra. Brophy, Jere. 2004. Motivating Students to Learn. New Jersey: Lawrence Erlbaum Associates Publishers.

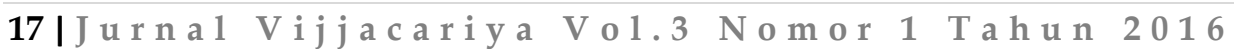


Corwin, Z. Blumberg \& Tierney, G. William. 2007. Getting There-and Beyond: Building a culture of College-going in High School. Los Angeles: Center for Higher Education Policy Analysis.

Desmita. 2010. Psikologi Perkembangan Peserta Didik: Panduan bagi Orang Tua dan Guru dalam Memahami Psikologi Anak Usia SD, SMP, dan SMA. Bandung: Remaja Rosdakarya.

Hidayat, H. Syarif dan Asroi. 2013. Manajemen Pendidikan: Substansi dan Implementasi dalam Praktik Pendidikan di Indonesia. Tangerang: Pustaka Mandiri.

Lunenburg, Fred C. 2011. Understanding Organizational Culture: A Key Leadership Asset. National Forum of Educational Administration and Supervision Journal, Vol. 29, No. 4, p. 1-12.

Maslowski, Ralf. 2001. School Culture and School Performance. Twente University Press: Thesis.

Mecneil, J. Angus, at al. 2009. The Effect of School Culture and Climate on Student Achievement. International Juornal of Leadership in Education, Vol. 12, No. 1, p. $73-84$.

Purwanto. 2007. Instrumen Penelitian Sosial dan Pendidikan. Yogyakarta: Pustaka Pelajar.

Rakhmat, Jalaluddin. 2012. Psikologi Komunikasi. Bandung: Remaja Rosdakarya. Reid, Gavin. 2009. Memotivasi Siswa di Kelas: Gagasan dan Strategi. Jakarta: Indeks.

Rusman. 2014. Pendidikan Saintifik dan Kontekstual dalam Pembelajaran Abad 21: Kunci Sukses Implementasi Kurikulum 2013. Bogor: Ghalia Indonesia.

Robbins, Stephen P. 2001. Perilaku Organisasi Jilid 2. Jakarta: Prenhallindo.

Saefullah, U. 2012. Psikologi Perkembangan dan Pendidikan. Bandung: Pustaka Setia.

Sardiman, A. M. 2006. Interaksi dan Motivasi Belajar Mengajar. Jakarta: Raja Grafindo Persada.

Sarwono, Sarlito W. 2012. Pengantar Psikologi Umum. Jakarta: Rajawali Pers.

Sekaran, Uma. 2006. Research Methods for Business. Jakarta: Salemba Empat.

Sobur, Alex. 2011. Psikologi Umum dalam Lintasan Sejarah. Bandung: Pustaka Setia.

Stolp, Stephen and Stuart C. Smith. 1995. Transforming School Culture: Stories, Symbols, Values and The Leader's Role. Michigan: University of Oregon.

Sudarman, Paryati. 2004. Belajar Efektif di Perguruan Tinggi. Bandung: Simbiosa Rekatama Media.

Sugiyono. 2013. Cara Mudah Menyusun: Skripsi, Tesis, dan Disertasi. Bandung: Alfabeta

Tampubolon, Manahan P. 2012. Perilaku Keorganisasian (Organization Behavior): Perspektif Organisasi Bisnis. Bogor: Ghalia Indonesia.

Uno, Hamzah B. 2008. Model Pembelajaran: Menciptakan Proses Belajar Mengajar yang Kreatif dan Efektif. Jakarta: Bumi Asksara.

Waldron, Nancy L. \& McLeskey. 2010. Estabilishing a CollaborativeSchool Culture Through Comprehensive School Reform. Journal of Educational and Psychological Consultation, 20, p. 58-74.

Wibowo. 2013. Perilaku dalam Organisasi. Jakarta: Raja Grafindo Persada.

Woolfolk, Anita. 2009. Educational Psychology Active Learning Edition. Yogyakarta: Pustaka Pelajar. 